\title{
RESEARCH
}

Open Access

\section{Regenerative cell therapy for pulmonary arterial hypertension in animal models: a systematic review}

Colin M. Suen 1,2, Duncan J. Stewart ${ }^{1,2,6}$, Joshua Montroy ${ }^{4,5}$, Christopher Welsh ${ }^{6}$, Brendan Levac ${ }^{6}$, Neil Wesch ${ }^{4,5}$, Alexander Zhai ${ }^{1}$, Dean Fergusson ${ }^{4,5,6,7,8}$, Lauralyn McIntyre ${ }^{4,5}$ and Manoj M. Lalu ${ }^{1,2,3,4,5^{*}}$ (D)

\begin{abstract}
Background: Pulmonary arterial hypertension $(\mathrm{PAH})$ is a rare disease characterized by widespread loss of the pulmonary microcirculation and elevated pulmonary arterial pressures leading to pathological right ventricular remodeling and ultimately right heart failure. Regenerative cell therapies could potentially restore the effective lung microcirculation and provide a curative therapy for PAH. The objective of this systematic review was to compare the efficacy of regenerative cell therapies in preclinical models of PAH.

Methods: A systematic search strategy was developed and executed. We included preclinical animal studies using regenerative cell therapy in experimental models of PAH. Primary outcomes were right ventricular systolic pressure (RVSP) and mean pulmonary arterial pressure (mPAP). The secondary outcome was right ventricle/left ventricle + septum weight ratio $(\mathrm{RV} / \mathrm{LV}+\mathrm{S})$. Pooled effect sizes were undertaken using random effects inverse variance models. Risk of bias and publication bias were assessed.

Results: The systematic search yielded 1285 studies, of which 44 met eligibility criteria. Treatment with regenerative cell therapy was associated with decreased RVSP (SMD - 2.10; 95\% Cl - 2.59 to - 1.60), mPAP (SMD - 2.16; 95\% Cl - 2.97 to -1.35$)$, and RV/LV+S (SMD - 1.31, 95\% Cl - 1.64 to - 0.97). Subgroup analysis demonstrated that cell modification resulted in greater reduction in RVSP. The effects on RVSP and mPAP remained statistically significant even after adjustment for publication bias. The majority of studies had an unclear risk of bias.
\end{abstract}

Conclusions: Preclinical studies of regenerative cell therapy demonstrated efficacy in animal models of PAH; however, future studies should consider incorporating design elements to reduce the risk of bias.

Systematic review registration: Suen CM, Zhai A, Lalu MM, Welsh C, Levac BM, Fergusson D, Mclntyre L and Stewart DJ. Efficacy and safety of regenerative cell therapy for pulmonary arterial hypertension in animal models: a preclinical systematic review protocol. Syst Rev. 2016;5:89.

Trial registration: CAMARADES-NC3Rs Preclinical Systematic Review \& Meta-analysis Facility (SyRF). http://syrf.org.uk/protocols/. Syst Rev 5:89, 2016

Keywords: Meta-analysis, Pulmonary hypertension, Cell therapy, Animal models of human disease

\footnotetext{
* Correspondence: manojlalu@gmail.com; mlalu@toh.ca

${ }^{1}$ Regenerative Medicine Program, The Ottawa Hospital Research Institute, 501

Smyth Road, PO Box 201B, Ottawa, ON K1H 8L6, Canada

${ }^{2}$ Department of Cell and Molecular Medicine, University of Ottawa, Ottawa,

Canada

Full list of author information is available at the end of the article
}

(C) The Author(s). 2019 Open Access This article is distributed under the terms of the Creative Commons Attribution 4.0 International License (http://creativecommons.org/licenses/by/4.0/), which permits unrestricted use, distribution, and reproduction in any medium, provided you give appropriate credit to the original author(s) and the source, provide a link to the Creative Commons license, and indicate if changes were made. The Creative Commons Public Domain Dedication waiver (http://creativecommons.org/publicdomain/zero/1.0/) applies to the data made available in this article, unless otherwise stated. 


\section{Background}

Pulmonary arterial hypertension (PAH) is a progressive disease associated with increased pulmonary vasculature resistance, increased pulmonary arterial pressure, and right heart failure [1]. The clinical diagnosis of pulmonary arterial hypertension (PAH) is defined by a mean pulmonary arterial pressure $\geq 25 \mathrm{mmHg}$ at rest and pulmonary capillary wedge pressure $\leq 15 \mathrm{mmHg}$ by right heart catheterization [2]. Although the mechanisms leading to PAH are still unclear, endothelial apoptosis is widely considered to be an initiating process that reduces the effective lung vasculature area through functional pulmonary microvascular rarefaction and obliterative remodeling of the small pulmonary arterioles due to the emergence of growth dysregulated vascular cells and endothelial cell dropout [3]. Ultimately, loss of lung microcirculation leads to progressive increases in pulmonary vascular resistance, right ventricular remodeling, and eventually right heart failure $[2,4,5]$.

Regenerative cell therapy has emerged as a novel treatment for PAH that has been examined in many preclinical animal studies and applied in several clinical trials $[6,7]$. The majority of preclinical models report the use of two main cell types: early-outgrowth endothelial progenitor cells (EPCs, also known as circulating angiogenic cells, myeloid angiogenic cells) and mesenchymal stromal cells (MSCs, also known as mesenchymal stem cells, adult stem cells) $[6,8]$. EPCs and MSCs have demonstrated the ability to migrate to sites of vascular injury in several in vivo animal disease models [9] secreting paracrine factors which induce vascular repair and reduce inflammation [6]. Preclinical studies involving EPCs and MSCs have demonstrated efficacy by reducing pulmonary pressures, regenerating lost microvascular area, and reducing both pulmonary vascular and right ventricular remodeling [6]. Three small clinical trials ( 2 adult, 1 pediatric) involving regenerative cell therapy on $\mathrm{PAH}$ patients have been completed and demonstrate some promise in limiting disease burden $[7,10,11]$. However, to date, there has been no systematic synthesis of preclinical studies investigating stem cell therapy for the treatment of PAH. A synthesis of this preclinical data may identify knowledge gaps, impact the design of further preclinical testing of cell therapies, and potentially influence the design of future clinical trials.

In this systematic review and meta-analysis, we quantified the effects of regenerative cell therapy on pulmonary hemodynamics based on currently available data in preclinical studies. Cells from all sources were considered, as well as all enhancements (e.g., gene transfected). We also provide a comprehensive review of study methodology, assessment of bias, and publication bias.

\section{Methods/design}

\section{Protocol and registration}

Our protocol was published [12] and also posted on the Collaborative Approach to Meta Analyses and Review of Animal Data from Experimental Studies (CAMRADES) website (http://syrf.org.uk). Reporting of this review adheres to the Preferred Reporting Items for Systematic Reviews and Meta-Analyses guidelines (Additional file 1) [13].

\section{Eligibility criteria}

We included interventional studies (randomized, pseudorandomized, and non-randomized) that examined an in vivo model of experimentally induced PAH comparing the effect of regenerative cell administration versus a diseased control. Both unmodified cells and enhanced cells (e.g., gene transfected) were considered. Valid preclinical in vivo models of PAH that reproduced features of the pathophysiology associated and/or etiology of human PAH [1] were the rodent monocrotaline (MCT) and SU5416 + chronic hypoxia $(\mathrm{SU}+\mathrm{CH})$ models. Prevention and treatment type studies were included. Mouse models were excluded in this systematic review as available models at the time of data extraction (chronic hypoxia) lacked significantly elevated pulmonary pressures, right ventricular hypertrophy, and pulmonary arteriolar remodeling [14]. Animal models of PAH secondary to other causes such as left heart disease, lung disease, or thromboembolism (WHO groups 3-5) [2] were excluded. Genetically modified animals and neonatal animal models were also excluded.

Outcomes were assessed at least 1 week after intervention to exclude the possibility of acute effects of cell administration. Our primary outcomes were measures of pulmonary hemodynamics (mean pulmonary arterial pressure, right ventricular systolic pressure). Secondary outcomes included survival and right ventricular (RV) remodeling expressed as the weight ratio of right ventricle/left ventricle + septum $(\mathrm{RV} / \mathrm{LV}+\mathrm{S})$.

\section{Literature search}

We searched Ovid MEDLINE, Ovid MEDLINE ${ }^{\bullet}$ InProcess \& Other Non-Indexed Citations, and EMBASE Classic+ until January 2018. The search strategy was developed by an information specialist and validated using the Peer Review of Electronic Search Strategies (PRESS) by another information specialist (Additional file 2) [15]. The search used combination of controlled vocabulary (for example stem cells, pulmonary hypertension), and keywords (for example EPC, MSC, iPSC, HSC, PAH) and parsing were formatted accordingly to each database. In addition, we performed a manual review of the bibliographies of selected articles and relevant reviews. 
Only articles in the English language were included in the review.

\section{Study selection process}

Citations from the literature search were collated, and duplicate studies removed. Titles and abstracts of search results were screened independently by two reviewers (CW, BL, NW, CS) using DistillerSR software (Evidence Partners, Ottawa, ON). Abstracts deemed potentially relevant were recorded, and full-text articles obtained. Remaining articles moved forward for full-text review, which was also performed in duplicate $(\mathrm{CW}, \mathrm{BL}, \mathrm{NW}$, $\mathrm{CS}$ ). Disagreements between reviewers were resolved by consensus or by a third-party consultation (DJS or MML). The study selection process was documented and reported using a PRISMA flow diagram (Fig. 1) [13].

\section{Data extraction and risk of bias assessment}

Data was extracted independently by two individuals into standardized, electronic pilot-tested forms. Data was collected on general study characteristics (e.g., study design, funding source, and origin), on regenerative cell characteristics (cell type, dose, enhancements, etc.), and on primary and secondary outcomes. Disagreements during extraction were resolved by consensus or third-party consultation (MML or DJS). In the case of missing or unclear data for the primary or secondary outcome measures, an attempt was made to contact the primary study author(s) for clarification. Risk of bias was assessed independently in duplicate for each included study using the SYRCLE (Systematic Review Centre for Laboratory animal Experimentation) risk of bias tool [16], and each parameter for the type of bias was scored as low, high, or unclear risk of bias.

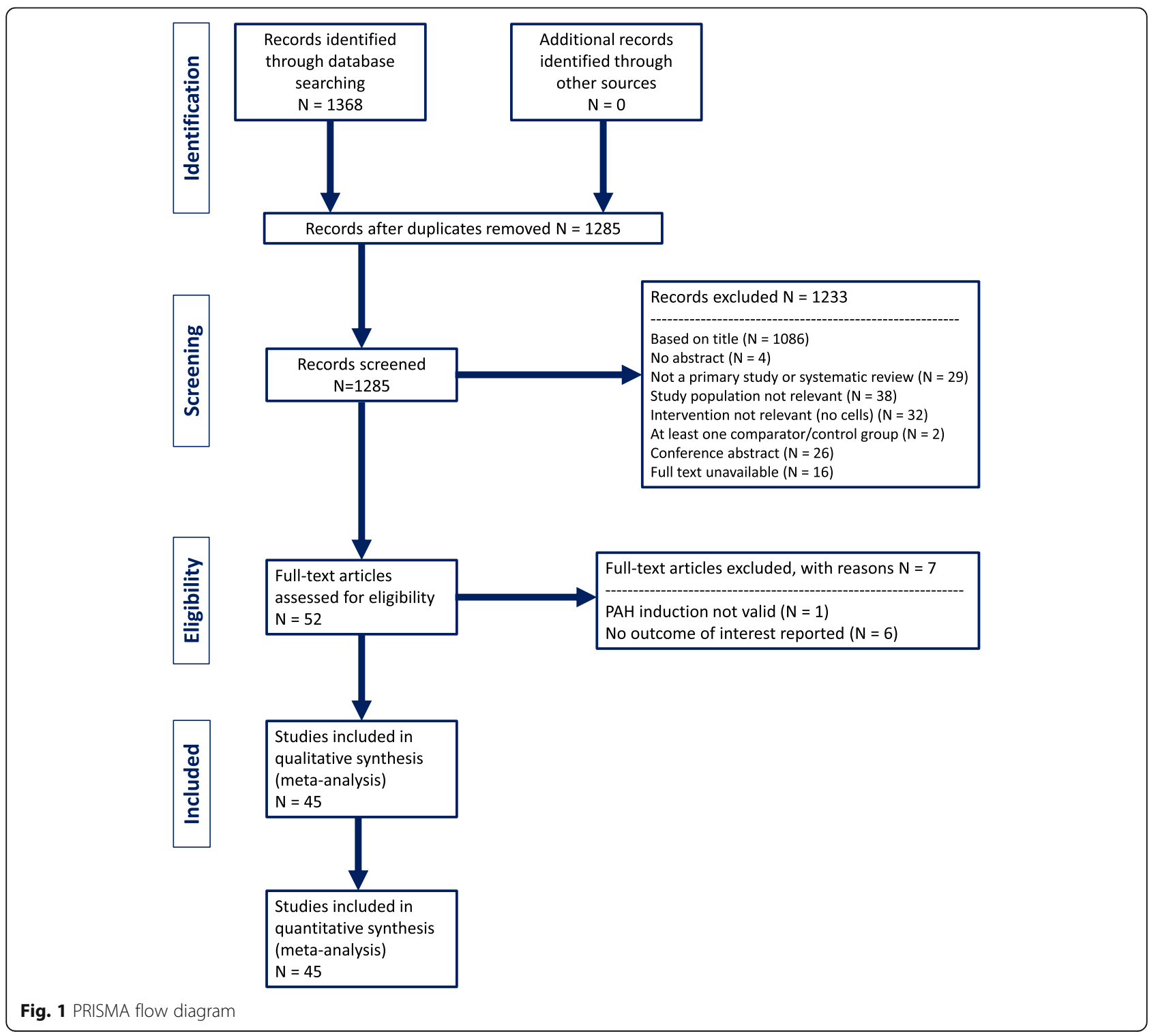




\section{Data analysis}

Studies were pooled using Comprehensive Meta-Analyst (v3; Biostat Inc., USA). For continuous endpoints, mean difference $(\mathrm{MD})$ or standardized mean difference (SMD) was calculated, depending on the measurement of the outcome. MD and SMD were calculated using random effects of inverse variance meta-analyses and presented with accompanying 95\% confidence intervals. For dichotomous outcomes, risk ratios were calculated using a random effects analysis based on the Der-Simonian Laird model and presented with accompanying 95\% confidence intervals. Statistical heterogeneity of included studies was measured using the $I^{2}$ statistic [17]. An $I^{2}$ value of $>50 \%$ was determined to indicate important heterogeneity worth further exploration. We assessed the potential for publication bias using funnel plots and Egger's regression test [18].

A priori defined subgroup analyses were examined on the primary endpoint of right heart catheterization hemodynamics (RVSP/mPAP). The pre-planned subgroups that were analyzed included regenerative cell type, cell enhancement (cell pretreatments/priming, gene transfection), and timing of administration. For timing of cell therapy, interventions administered prior to 14 days were considered "early" based on the rat monocrotaline model (where hemodynamic changes are not noted prior to this timepoint after disease induction) [14]. A post hoc subgroup analysis was performed examing the effect of cell compatibility (i.e., allogeneic and xenogeneic) on the primary endpoint of right heart catheterization hemodynamics (RVSP/mPAP). In addition, we performed post hoc subgroup analysis exploring the effect of cell dose and cell origin (bone marrow, umbilical, adipose) on studies which administered MSCs.

\section{Results}

\section{Study characteristics}

Our systematic search yielded a total of 1285 articles. After preliminary screening, 94 articles were identified for full-text review, of which 45 studies met eligibility criteria for this review (Fig. 1). Baseline characteristics are reported in Table 1 . Studies were published between 2003 and 2017, with 14 studies from China, 8 studies from the USA, 6 studies from Korea, 6 studies from Japan, 5 from Taiwan, 2 from Canada, and 1 each from Netherlands, Brazil, Egypt, and Italy. Sample size ranged from 7 to 51, and follow-up duration ranged from 7 to 173 days. The majority of the studies were conducted in rats (43 out of 45 ), with 2 studies in dogs [19, 20].

Studied cell types included bone marrow mononuclear cell (BM-MNC) $(n=3), \quad$ cardiosphere-derived cells (CDC) $(n=1)$, endothelial progenitor cell (EPC) $(n=13)$, induced pluripotent stem cell (iPSC) $(n=1)$, and mesenchymal stem cell (MSC) $(n=27)$. Forty-one studies
(91\%) administered the cells intravenously, three studies (7\%) administered the cells intratracheally, and one study (2\%) administered the cell intra-peritoneally. The cell dose used ranged from 100,000 total cells to 20 million total cells. The timing of cell administration ranged from immediately following PAH induction to 35 days post$\mathrm{PAH}$ induction. Seventeen studies used cell enhancement strategies, and 28 studies did not. All studies used a fresh cell product.

\section{Primary outcomes \\ Right ventricular systolic pressure (RVSP)}

Twenty-six studies reported data on RVSP from 44 experiments (805 animals). Cell therapy was associated with a significant reduction in RVSP compared to control (SMD -2.10 ; $95 \%$ CI -2.59 to -1.60 ) (Fig. 2a). In a post hoc analysis using weighted mean difference (WMD), animals which had received regenerative cell therapy saw a 13.7-mmHg reduction in RVSP (95\% CI - 16.2 to - 11.1) (Additional file 3: Figure S1).

The treatment effect was analyzed by pre-defined subgroups (cell type, cell enhancement, and timing of treatment, species). Cell enhancement by gene transfection or small molecule pretreatment/priming was associated with a greater reduction in RVSP compared to non-enhanced cells (Fig. 2b) $(p=0.001)$. Subgroup analysis by cell type showed significant reductions in RVSP for all cell types, with the exception of bone marrow mononuclear cells (Fig. 2c). For bone marrow mononuclear cells (BM-MNC) and cardiosphere-derived cells (CDC) cell types, only one study was available to contribute data to each. Post hoc analysis demonstrated that MSCs had a significantly greater effect in lowering RVSP than EPCs $(p<0.001)$. Cell therapy administered at 14 days or later was associated with a greater reduction in RVSP compared to cell therapy administered less than 14 post disease induction (Fig. 2d). In a post hoc subgroup analysis of cell compatibility, there was no difference in effect between allogeneic, autologous, or xenogeneic cell therapy (Additional file 3: Figure S2).

Visual inspection of the funnel plot indicated potential publication bias, which was supported by Egger's regression $(p<0.001)$. Post hoc trim and fill analysis suggests a $45 \%$ overestimation of effect. Accounting for potential publication bias, cell therapy remained associated with a significant reduction in RVSP (SMD - 1.45; 95\% CI - 1.98 to -0.92 ) (Additional file 3: Figure S3). In post hoc analyses of MSC studies only, there was no difference in effect between high vs low dose, or MSC source (Additional file 3: Figures S4-S5).

\section{Mean pulmonary arterial pressure (mPAP)}

Eleven studies (16 experiments) reported data on mPAP (16 experiments, 233 animals). Overall, regenerative cell 


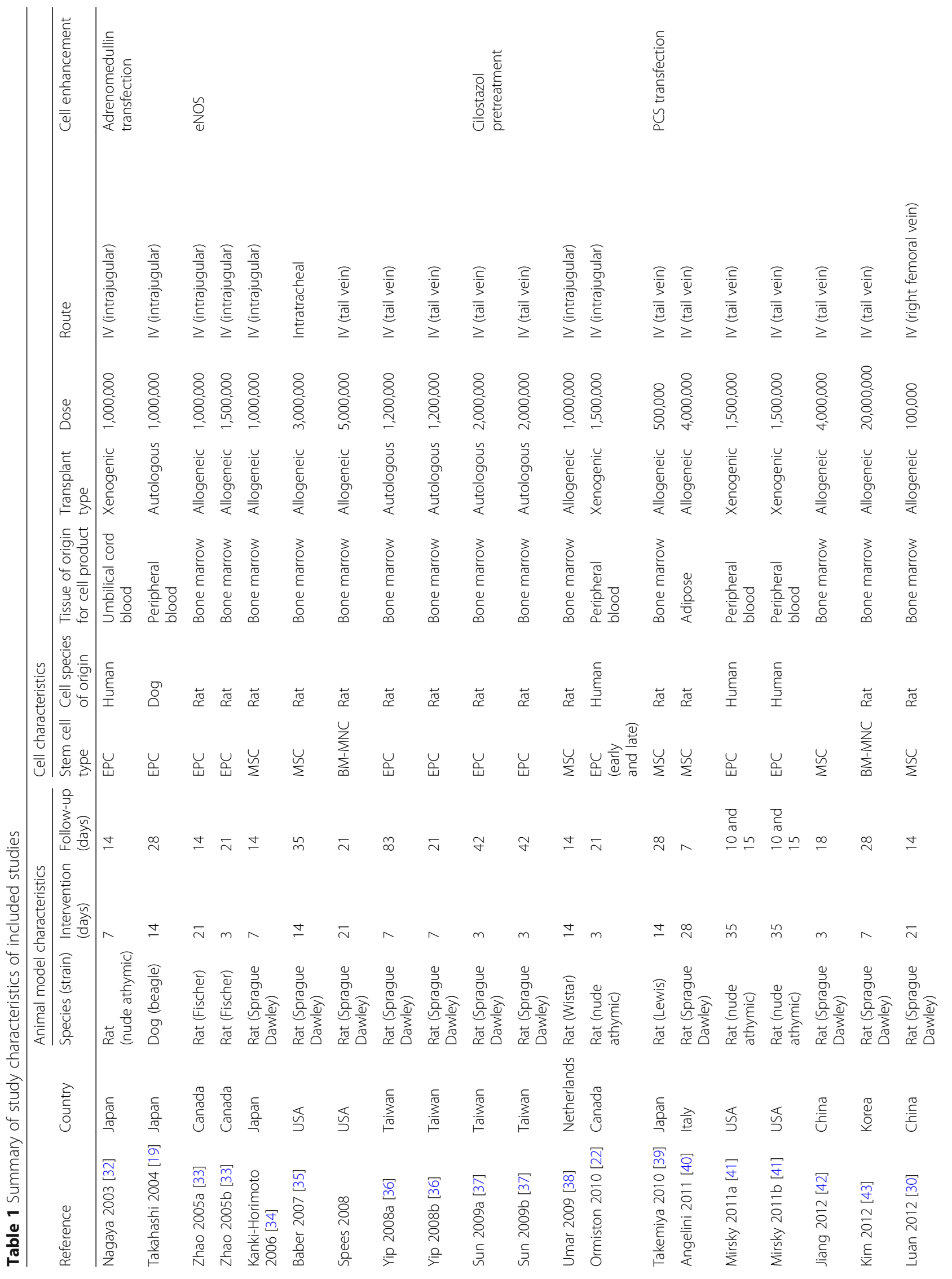




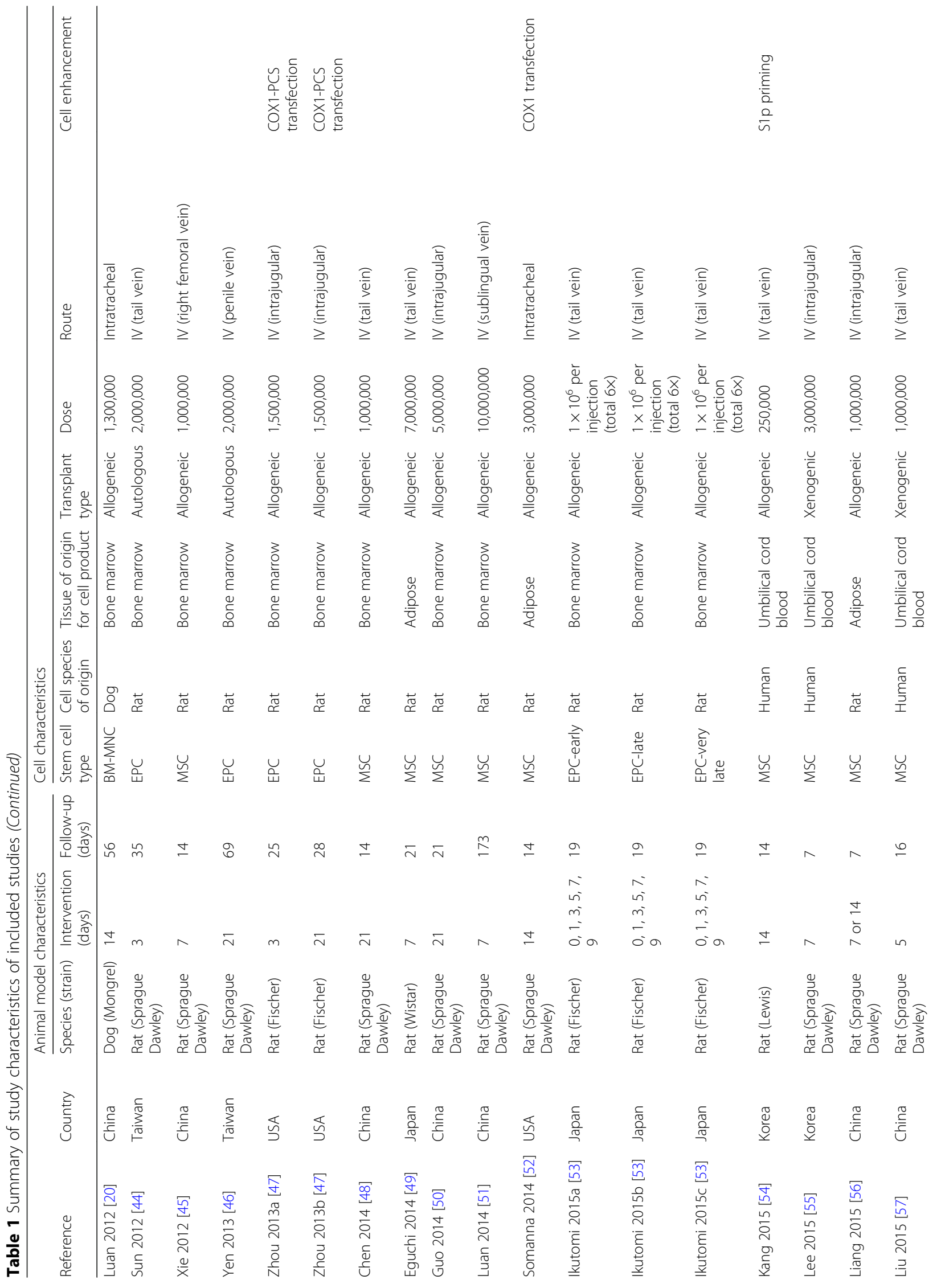




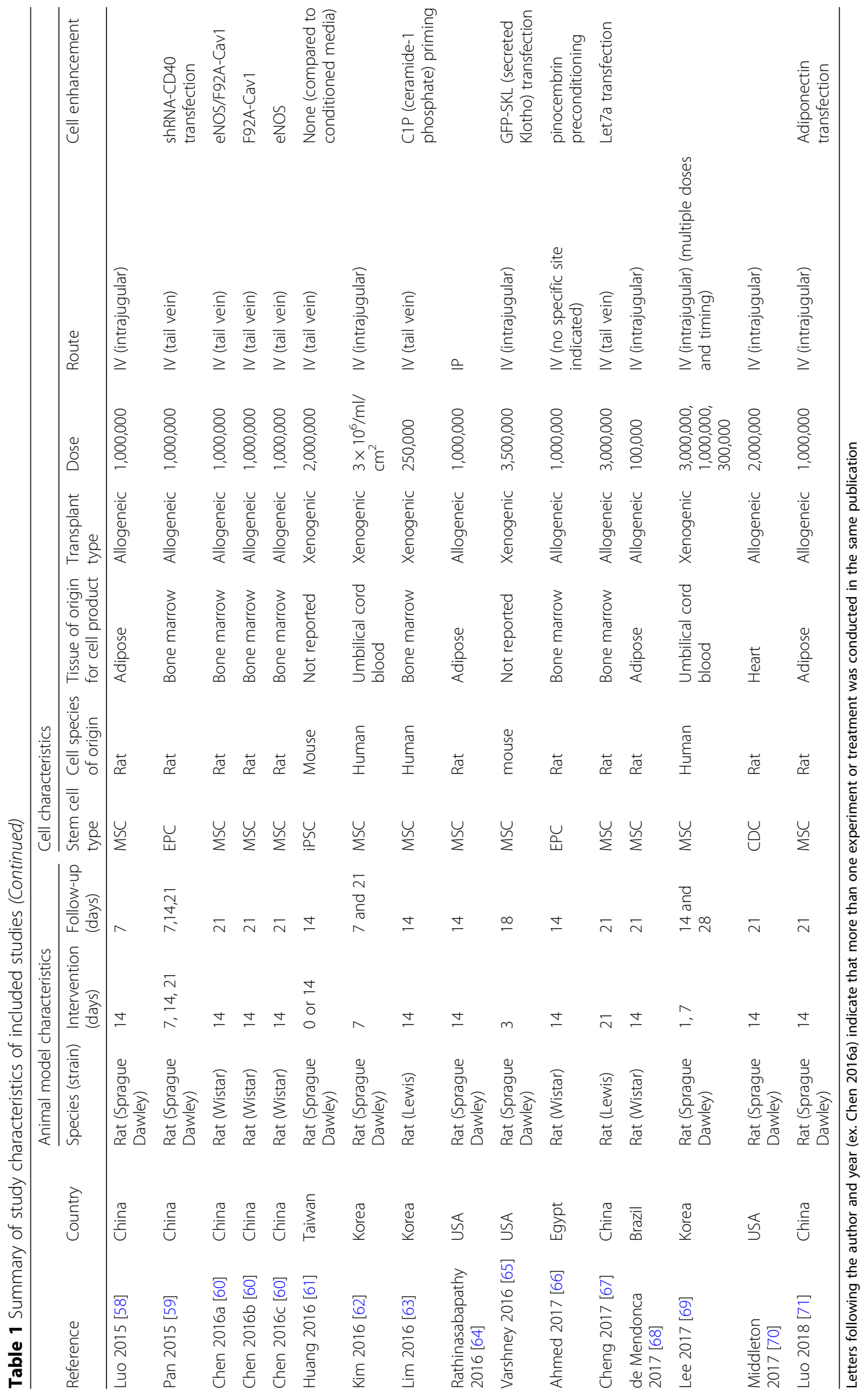




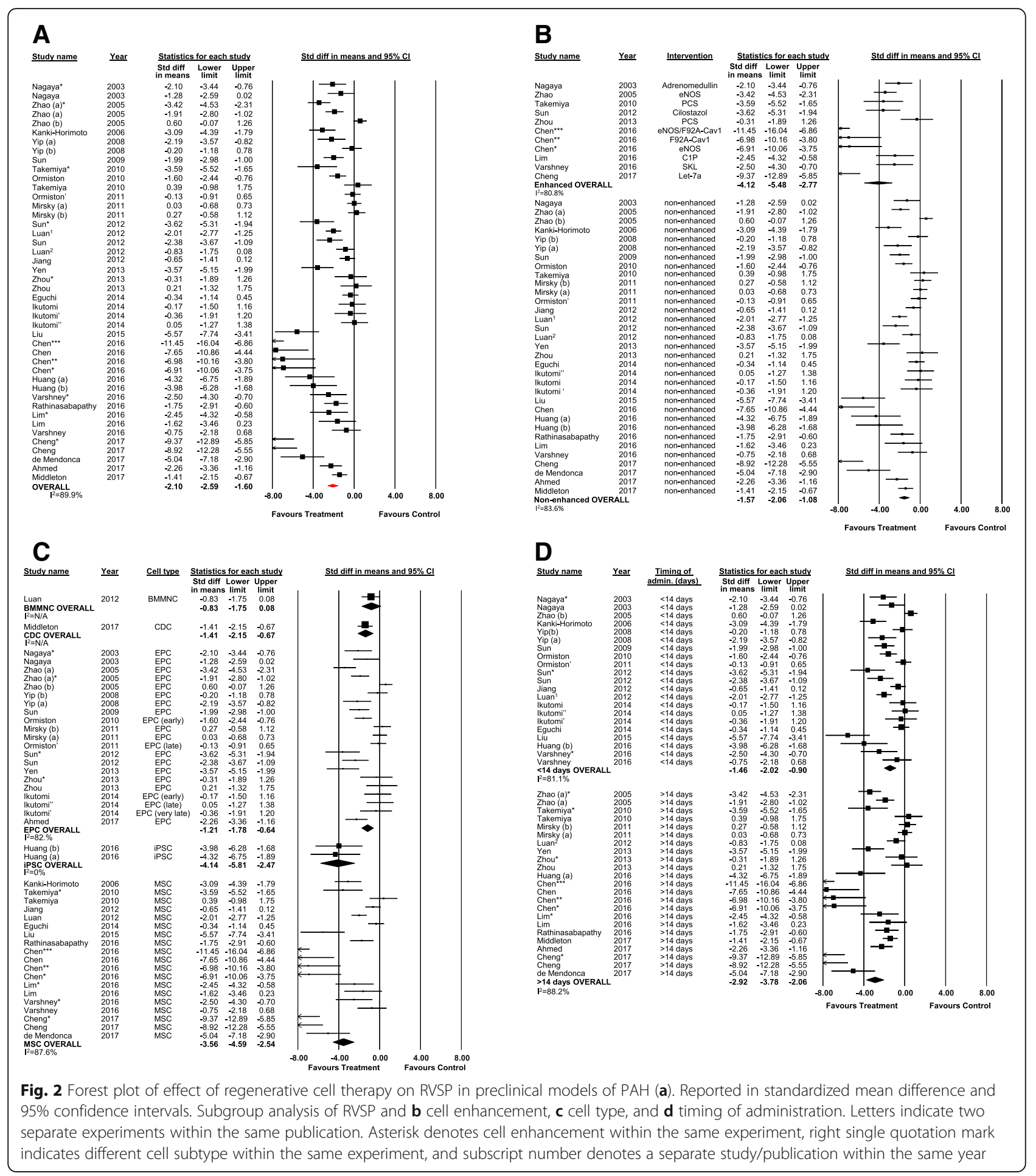

therapy was associated with a significant reduction in mPAP compared to control (SMD - 2.16; 95\% CI - 2.97 to -1.35 ) (Fig. 3a). There was no difference in effect between enhanced and non-enhanced cells, although data from enhanced cell studies was sparse $(n=3)$ (Fig. 3b). Subgroup analysis by cell type showed significant reductions in mPAP for treatment with EPC and MSC; however, post hoc analysis demonstrated no significant benefit of one cell type over the other (Fig. 3c). Subgroup analysis by timing of treatment suggests efficacy when cell therapy was administered at less than 21 days (Fig. 3d). In a post hoc subgroup analysis of cell compatibility, there was no difference in effect between allogeneic, autologous, or xenogeneic cell therapy (Additional file 3: Figure S6). 


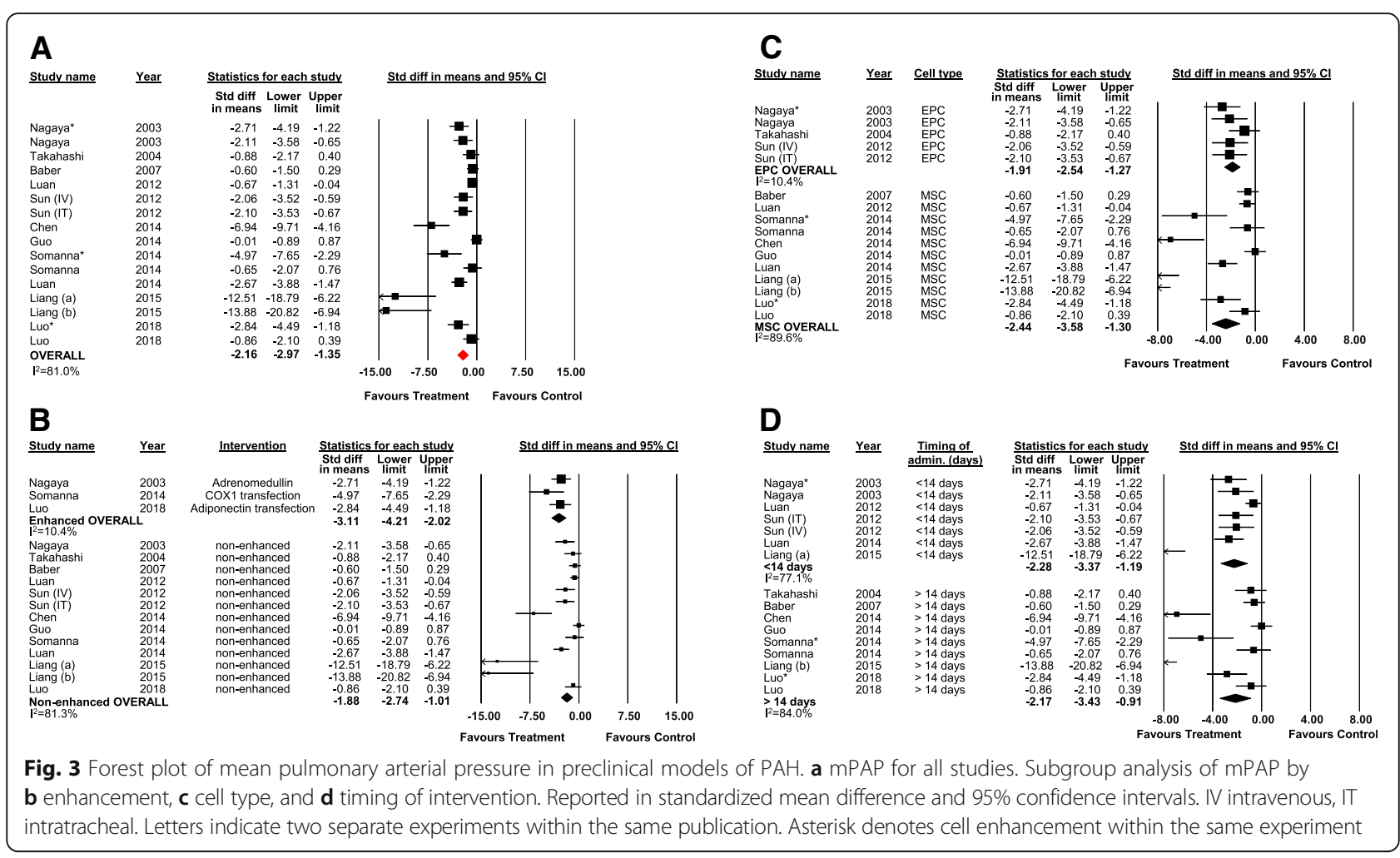

Visual inspection of the funnel plot indicated potential publication bias, which was confirmed by Egger's regression $(p<0.001)$ (Additional file 3: Figure S7). Post hoc trim and fill analysis suggests a $5 \%$ overestimation of effect. Accounting for potential publication bias, cell therapy remained associated with a significant reduction in $\mathrm{mPAP}$ (SMD - 2.05; 95\% CI -2.90 to -1.21) (Additional file 3: Figure S7). In post hoc analyses of MSC studies only, there was no difference in effect between different MSC sources; however, a larger effect was observed with a low dose of cells $(<1$ million cells) (Additional file 3: Figures S8-S9).

\section{Secondary outcomes}

Twenty-nine studies (50 experiments) reported $\mathrm{RV} / \mathrm{LV}+\mathrm{S}$ from 930 animals. Regenerative cell therapy was associated with an overall decrease in RV remodeling measured by RV/LV+S (SMD - 1.31, 95\% CI - 1.64 to - 0.97) (Fig. 4). Three studies reported data on mortality (87 animals). No statistically significant difference in mortality was observed between groups (RR 2.11, 95\% CI 0.12 to 36.04) (Additional file 3: Figure S10).

\section{Risk of bias (SYRCLE tool)}

Most studies were rated for unclear risk of bias across all categories (Fig. 5), reflecting incomplete reporting of methodological details. Twenty-two studies (49\%) described randomizing animals to treatment and control groups. Two studies (4\%) reported blinding the experimenters, while seven studies (16\%) reported blinding of outcome assessment. The risk of bias was unclear for all studies across the domains of allocation concealment, baseline characteristic description, random animal housing, random outcome assessment, incomplete outcome data, and selective reporting of outcomes.

\section{Discussion}

Our systematic review is the first to examine the effect of regenerative cell therapy in preclinical models of $\mathrm{PAH}$. Overall, the results of our meta-analysis demonstrate an improvement in the primary outcome hemodynamics (RVSP, mPAP) and the secondary outcome RV remodeling $(\mathrm{RV} / \mathrm{LV}+\mathrm{S})$ with regenerative cell therapy. Subgroup analysis showed that the reduction in RVSP was observed in MSC, EPC, and iPSC cell types. Additional subgroup analysis on timing of treatment showed that regenerative cell therapy administered at $3,7,14$, and 21 days post-induction resulted in significant reductions in RVSP. Efficacy was still observed when treatment was administered beyond 14 days post-induction during established $\mathrm{PAH}$, which represents a clinically meaningful timepoint for intervention.

Several studies included in this meta-analysis examined the utility of cell enhancement strategies such as gene transfection or pharmacological preconditioning. Overall, cell enhancement was associated with greater 
reduction in RVSP and mPAP compared to treatment with non-enhanced cells. A caveat with this interpretation is that there is potential for publication bias, as ineffective enhancement strategies are less likely to be pursued and published. As well, due to the limited number of studies for each enhancement strategy, we could not compare between gene candidates or preconditioning.

All 45 studies were performed in the MCT model of $\mathrm{PAH}$, and all performed in a male population of rats ( $n=43$ studies) or dogs ( $n=2$ studies) and therefore, the generalizability of these findings may be limited. The MCT model has been criticized for its off-target systemic toxicity to the liver, heart, and kidneys, which also limits the long-term study of treatments in preclinical studies. In recent years, the SU5416 + chronic hypoxia model of PAH has been considered the most representative model of human PAH due to its ability to closely replicate the salient histopathological features of PAH in humans and the profound changes in pulmonary hemodynamics [14, 21]. Ideally, confirmatory studies in both models would improve validity; however, our systematic search did not identify any studies involving regenerative cell therapy in the SU5416 + chronic hypoxia model.

One of the limitations of this study is that we did not assess histopathological data such as pulmonary vascular remodeling or cell engraftment. Regenerative cell 


\begin{tabular}{|c|c|c|c|c|c|c|c|c|c|c|}
\hline & 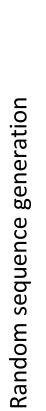 & 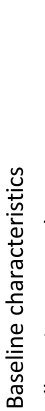 & 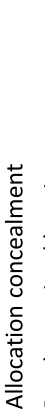 & 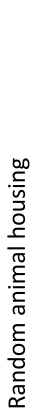 & 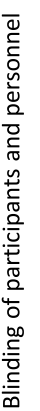 & 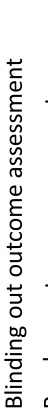 & 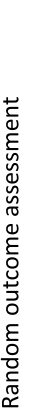 & 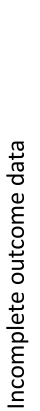 & 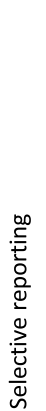 & 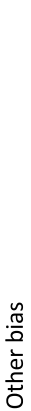 \\
\hline Ahmed 2017 & (†) & \begin{tabular}{|l|l|}
$?$ \\
\end{tabular} & \begin{tabular}{|l|l}
$?$ \\
\end{tabular} & \begin{tabular}{|l|l}
$?$ \\
\end{tabular} & ? & $?$ & $?$ & \begin{tabular}{|l|l}
$?$ \\
\end{tabular} & \begin{tabular}{|l|l}
$?$ \\
\end{tabular} & $?$ \\
\hline Angelini 2017 & $?$ & $?$ & 3 & 3 & $?$ & 3 & $?$ & $?$ & \begin{tabular}{|l|l}
$?$ \\
\end{tabular} & $?$ \\
\hline Baber 2007 & $?$ & $?$ & $?$ & $?$ & ? & $?$ & $?$ & $?$ & \begin{tabular}{|l|l} 
\\
\end{tabular} & ? \\
\hline Chen 2014 & $?$ & $?$ & 3 & $?$ & ? & 3 & $?$ & $?$ & \begin{tabular}{|l|l|l|}
$?$ \\
\end{tabular} & $?$ \\
\hline Chen 2017 & ๑) & $?$ & $?$ & $?$ & ? & () & $?$ & ? & ? & $?$ \\
\hline Cheng 2017 & (๑) & $?$ & 3 & 3 & ? & 3 & $?$ & 3 & ? & $?$ \\
\hline Eguchi 2014 & $?$ & $?$ & $?$ & $?$ & ๑) & 3 & $?$ & $?$ & ? & $?$ \\
\hline Guo 2014 & $?$ & $?$ & $?$ & $?$ & $?$ & 3 & $?$ & $?$ & \begin{tabular}{|l|l}
$?$ \\
\end{tabular} & $?$ \\
\hline Huang 2016 & () & $?$ & $?$ & $?$ & $?$ & $?$ & $?$ & $?$ & \begin{tabular}{|l|l} 
\\
\end{tabular} & $?$ \\
\hline Ikutomi 2015 & (†) & $?$ & $?$ & $?$ & $?$ & 3 & $?$ & $?$ & $?$ & $?$ \\
\hline Jiang 2012 & ๑) & $?$ & $?$ & 3 & $?$ & 3 & $?$ & $?$ & \begin{tabular}{|l|l} 
\\
\end{tabular} & $?$ \\
\hline Kang 2015 & $?$ & $?$ & $?$ & $?$ & ? & 3 & $?$ & $?$ & $?$ & $?$ \\
\hline Kanki-Horimoto 2006 & $?$ & $?$ & $?$ & $?$ & ? & 3 & $?$ & $?$ & \begin{tabular}{|l|l|l|l} 
\\
\end{tabular} & $?$ \\
\hline Kim 2012 & $?$ & $?$ & $?$ & $?$ & $?$ & 3 & $?$ & $?$ & \begin{tabular}{|l|}
$?$ \\
\end{tabular} & $?$ \\
\hline Kim 2016 & - & $?$ & 3 & $?$ & $?$ & 3 & $?$ & $?$ & \begin{tabular}{|l|l|} 
\\
\end{tabular} & $?$ \\
\hline Lee 2015 & $?$ & $?$ & $?$ & $?$ & ? & 3 & $?$ & $?$ & $?$ & $?$ \\
\hline Lee 2017 & ๑ & $?$ & ? & ? & $?$ & 3 & $?$ & $?$ & \begin{tabular}{|l|l|}
$?$ \\
\end{tabular} & $?$ \\
\hline Liang 2015 & (†) & $?$ & $?$ & $?$ & $?$ & 3 & $?$ & $?$ & ? & $?$ \\
\hline Lim 2016 & $?$ & $?$ & $?$ & $?$ & $?$ & 3 & $?$ & $?$ & \begin{tabular}{|l|l}
$?$ \\
\end{tabular} & $?$ \\
\hline Liu 2015 & () & $?$ & $?$ & $?$ & ? & 3 & $?$ & $?$ & $?$ & $?$ \\
\hline Luan 2012 (a) & † & $?$ & 3 & $?$ & $?$ & \begin{tabular}{|l|l}
$?$ \\
\end{tabular} & $?$ & $?$ & \begin{tabular}{|l|l}
$?$ \\
\end{tabular} & $?$ \\
\hline Luan 2012 (b) & ๑) & ? & $?$ & ? & ? & ๑) & $?$ & $?$ & \begin{tabular}{|l|l} 
\\
\end{tabular} & $?$ \\
\hline Luan 2014 & $?$ & $?$ & $?$ & $?$ & $?$ & ? & $?$ & $?$ & \begin{tabular}{|l|l}
$?$ \\
\end{tabular} & $?$ \\
\hline Luo 2015 & ๑) & ? & ? & ? & $?$ & ๑) & $?$ & $?$ & \begin{tabular}{|l|l}
$?$ \\
\end{tabular} & $?$ \\
\hline Luo 2018 & ๑) & $?$ & 3 & $?$ & $?$ & (๑) & $?$ & $?$ & \begin{tabular}{|l|l}
$?$ \\
\end{tabular} & $?$ \\
\hline Mendonca 2017 & ๑) & $?$ & $?$ & $?$ & $?$ & (†) & $?$ & $?$ & \begin{tabular}{|l|l}
$?$ \\
\end{tabular} & $?$ \\
\hline Middleton 2017 & (†) & $?$ & ? & $?$ & $?$ & (†) & $?$ & $?$ & \begin{tabular}{|l|l|}
$?$ \\
\end{tabular} & $?$ \\
\hline Mirsky 2011 & $?$ & $?$ & ? & $?$ & $?$ & \begin{tabular}{l|l}
$?$ \\
\end{tabular} & $?$ & $?$ & \begin{tabular}{|l|l|}
3 & \\
\end{tabular} & $?$ \\
\hline Nagaya 2003 & $?$ & $?$ & 3 & $?$ & $?$ & \begin{tabular}{l|l}
$?$ \\
\end{tabular} & $?$ & $?$ & \begin{tabular}{|l|l|}
$?$ \\
\end{tabular} & $?$ \\
\hline Ormiston 2010 & ๑ & 3 & 3 & 3 & 3 & 3 & $?$ & $?$ & 3 & $?$ \\
\hline Pan 2015 & (†) & $?$ & ? & $?$ & $?$ & \begin{tabular}{l|l}
$?$ \\
\end{tabular} & $?$ & $?$ & \begin{tabular}{|l|l}
$?$ \\
\end{tabular} & $?$ \\
\hline Rathinasabapathy 2016 & ๑) & $?$ & 3 & $?$ & $?$ & ๑) & $?$ & $?$ & \begin{tabular}{|l|l|}
3 \\
\end{tabular} & $?$ \\
\hline Somanna 2014 & $?$ & $?$ & ? & $?$ & $?$ & \begin{tabular}{l|l}
3 \\
\end{tabular} & $?$ & $?$ & ? & $?$ \\
\hline Sun 2009 & () & $?$ & 3 & $?$ & $?$ & \begin{tabular}{l|l}
$?$ \\
\end{tabular} & $?$ & 3 & \begin{tabular}{|l|l|}
3 \\
\end{tabular} & $?$ \\
\hline Sun 2012 & $?$ & $?$ & 3 & $?$ & $?$ & \begin{tabular}{l|l}
$?$ \\
\end{tabular} & $?$ & $?$ & \begin{tabular}{|l|l}
$?$ \\
\end{tabular} & $?$ \\
\hline Takahashi 2004 & $?$ & $?$ & 3 & 3 & $?$ & \begin{tabular}{l|l}
$?$ \\
\end{tabular} & $?$ & $?$ & \begin{tabular}{|l|l|}
$?$ \\
\end{tabular} & $?$ \\
\hline Takemiya 2010 & (†) & $?$ & $?$ & $?$ & $?$ & \begin{tabular}{l|l}
$?$ \\
\end{tabular} & $?$ & $?$ & \begin{tabular}{|l|l}
$?$ \\
\end{tabular} & $?$ \\
\hline Umar 2009 & $?$ & $?$ & 3 & $?$ & $?$ & \begin{tabular}{l|l}
$?$ \\
\end{tabular} & $?$ & $?$ & \begin{tabular}{|l|l|}
$?$ \\
\end{tabular} & $?$ \\
\hline Varshney 2016 & $?$ & $?$ & $?$ & $?$ & $?$ & \begin{tabular}{l|l}
$?$ \\
\end{tabular} & $?$ & $?$ & \begin{tabular}{|l|l}
$?$ \\
\end{tabular} & $?$ \\
\hline Xie 2012 & ๑) & $?$ & 3 & $?$ & $?$ & \begin{tabular}{l|l}
$?$ \\
\end{tabular} & $?$ & $?$ & \begin{tabular}{|l|l|}
$?$ \\
\end{tabular} & $?$ \\
\hline Yen 2013 & $?$ & $?$ & $?$ & $?$ & $?$ & \begin{tabular}{l|l} 
\\
\end{tabular} & $?$ & $?$ & ? & $?$ \\
\hline Yip 2008 & $?$ & $?$ & ? & $?$ & ๑ & \begin{tabular}{l|l}
$?$ \\
\end{tabular} & $?$ & $?$ & \begin{tabular}{|l|l|}
$?$ \\
\end{tabular} & $?$ \\
\hline Zhao 2005 & $?$ & $?$ & $?$ & $?$ & $?$ & \begin{tabular}{l|l}
$?$ \\
\end{tabular} & $?$ & $?$ & \begin{tabular}{|l|l}
$?$ \\
\end{tabular} & $?$ \\
\hline Zhou 2013 & $?$ & $?$ & $?$ & ? & $?$ & \begin{tabular}{l|l}
$?$ \\
\end{tabular} & $?$ & $?$ & \begin{tabular}{|l|l}
$?$ \\
\end{tabular} & $?$ \\
\hline
\end{tabular}

Fig. 5 Risk of bias assessment using the SYRCLE tool therapy has been proposed to alter pulmonary vascular remodeling, perhaps by reducing endothelial apoptosis and limiting smooth muscle hyperplasia, and could therefore be a useful surrogate outcome to assess efficacy [8]. However, the lack of consensus scoring systems for assessing pulmonary vascular remodeling in vivo limited our ability to include this in the analysis. Indeed, metrics such as wall thickening, medial hypertrophy, and so forth have been reported, but the scoring criteria were often vague, subjective, and non standardized. As well, cell retention or engraftment in the pulmonary vasculature would support the vascular remodeling hypothesis of cell therapy. Similarly, we found that engraftment was measured by several methods including immunofluorescence staining, transfection with fluorescent tag, or PCR. Within the same study, different techniques (e.g., immunofluorescence vs PCR) yielded variable cell retention rates [22], likely due to differences in sensitivity and specificity for each technique.

Another limitation of this analysis is that functional outcome measurements were not available. In clinical trials, the 6-min walk test is widely used, [23]; however, no such standardized functional assessment exists for animal studies. Instead, other surrogate measures of RV function may be available. Indeed, RV function is arguably the most important predictor of prognosis in PAH [24]. However, accurate quantification of RV ejection fraction in small animals due to the unique and variable geometry of the RV is challenging [14, 23]. RV dysfunction precedes mortality, and therefore, assessment of RV function could be a useful tool for clinical translation. Tricuspid annular planar systolic excursion (TAPSE) and RV fractional area change are 2D echocardiography measures that were rarely reported in preclinical studies $[23,25]$ and thus not included in the meta-analysis. Future studies examining the effect of regenerative cell therapy on cardiac output $(\mathrm{CO})$, cardiac index, or other indices of RV function may provide further insight into the long-term effects of cell therapy. Reporting of important outcomes such as cardiac output and pulmonary vascular resistance (PVR) was almost non-existent in included studies, and therefore, the effect of regenerative cell therapy on these outcomes could not be assessed.

Overall, the studies included in this systematic review were scored as having an unclear or high risk of bias using the itemized SYRCLE Risk of Bias tool for preclinical studies. For instance, although most studies randomize treatment, further measures to minimize bias such as allocation concealment or method of randomization were not reported. This information is critical, as inadequate generation or concealment of allocation is associated with exaggerated effect sizes [26]. Similarly, lack of blinding of outcome assessment, in which study investigators are unaware of the intervention allocation, is also associated with 
overestimation of effect size [27]. Only eight of the included studies reported blinding of outcome assessment. The lack of reporting of key potential sources of bias is consistent with preclinical literature in general. Although several preclinical reporting guidelines have been proposed to enhance transparency and methodological quality in preclinical studies [28], uptake by authors and journals has not been widespread. This lack of transparency contributes to poor reproducibility from preclinical to clinical trials, which is already strained as only $<5 \%$ of basic science discoveries are eventually approved by health authorities [29]. The identification of poor methodological reporting, as well as a lack of reporting of important outcomes such as CO and PVR, has identified a knowledge gap and represents a potential next step for future studies in the field.

In conclusion, regenerative cell therapy is associated with improved pulmonary hemodynamics and RV remodeling across several subgroups. The strengths of this study include the large number of studies [30], comprehensive data collection on model and treatment methodology, and subgroup analysis by cell enhancement, cell type, and timing, which can be used to inform future preclinical studies and clinical trials. The timing of this review is highly relevant, as small clinical trials have been completed (NCT00257413, NCT00641836, NCT00469027) [10, 11, 31]. So far, based on limited short-term data, the results of completed clinical trials have shown relatively modest benefits [10] compared to the effect sizes reported in some preclinical literature $[32,33]$. The effect sizes in our review may be influenced in part by potential sources of bias, which may be improved by increased methodological rigor which include randomization, allocation concealment, and blinding in future studies. Alternatively, the difference in effect size could be contributed by the relative homogeneity of animal models of $\mathrm{PAH}$, for example the rodent monocrotaline model, compared to clinical presentations of PAH. Future studies to address the validity of preclinical studies should also include the use of more comprehensive assessments of cardiac function, particularly the RV functional capacity, as well as follow-up confirmatory studies in multiple animal models such as the SU5416 + hypoxia model [27]. Several variations in regenerative cell therapy methods were evaluated for heterogeneity such as cell type, enhancement, and timing of administration. However, at this time, limited data and lack of head-to-head comparisons preclude the suggestion of an optimal method of cell therapy.

\section{Additional files}

Additional file 1: PRISMA Checklist. (DOCX $19 \mathrm{~kb}$ )

Additional file 2: Search strategy and PRESS review. (DOCX $34 \mathrm{~kb}$ )
Additional file 3: Figure S1. Post hoc analysis of RVSP using mean difference (MD). Figure S2. Post hoc analysis of RVSP subgrouped by cell compatibility. Figure S3. Funnel plot indicating possible publication bias for RVSP. Open circles are included studies and black circles represent imputed studies from post hoc trim and fill analysis. Figure S4. Post hoc analysis of RVSP subgrouped by cell origin (MSC studies only). Figure S5. Post hoc analysis of RVSP subgrouped by cell dose (MSC studies only). Figure S6. Post hoc analysis of MPAP subgrouped by cell compatibility. Figure S7. Funnel plot indicating possible publication bias for MPAP. Open circles are included studies and black circles represent imputed studies from post hoc trim and fill analysis. Figure S8. Post hoc analysis of mPAP subgrouped by cell origin (MSC studies only). Figure S9. Post hoc analysis of mPAP subgrouped by cell dose (MSC studies only). Figure S10. Risk ratio and accompanying 95\% confidence intervals for the risk of mortality. (DOCX $389 \mathrm{~kb}$ )

\section{Acknowledgements}

CS holds a Vanier Canada Graduate Scholarship and a Canadian Institutes of Health Research Training Program in Regenerative Medicine fellowship. We would like to thank Becky Skidmore (Information Specialist) and Risa Shorr (Librarian, The Ottawa Hospital) for providing assistance with the generation of a systematic search strategy and article retrieval. MML is supported by The Ottawa Hospital Anesthesia Alternate Funds Association and the Scholarship Protected Time Program, Department of Anesthesiology and Pain Medicine, uOttawa.

\section{Funding}

No specific funding was provided for this work.

\section{Availability of data and materials}

All data generated or analyzed during this study are included in this published article [and its supplementary information files].

\section{Authors' contributions}

$C S, A Z$, and DS conceived the study design. CS and ML were responsible for the initial drafting of the manuscript. CW, BL, and NW were responsible for the data collection. DS, ML, LM, and DF provided critical revisions for important intellectual content. All authors have reviewed and approved the final version of the manuscript.

\section{Ethics approval and consent to participate}

N/A.

\section{Consent for publication}

N/A.

\section{Competing interests}

DS is an unpaid consultant and has an equity interest in Northern Therapeutics (Montréal, QC, Canada). The other authors declare that they have no competing interests.

\section{Publisher's Note}

Springer Nature remains neutral with regard to jurisdictional claims in published maps and institutional affiliations.

\section{Author details}

${ }^{1}$ Regenerative Medicine Program, The Ottawa Hospital Research Institute, 501 Smyth Road, PO Box 201B, Ottawa, ON K1H 8L6, Canada. ${ }^{2}$ Department of Cell and Molecular Medicine, University of Ottawa, Ottawa, Canada.

${ }^{3}$ Department of Anesthesiology and Pain Medicine, The Ottawa Hospital, The Ottawa Hospital Research Institute, Ottawa, Canada. ${ }^{4}$ Clinical Epidemiology Program, Ottawa, Canada. ${ }^{5}$ Blueprint Translational Research Group, The Ottawa Hospital Research Institute, Ottawa, Canada. ${ }^{6}$ Department of Medicine, University of Ottawa, Ottawa, Canada. ${ }^{7}$ Depatrment of Surgery, University of Ottawa, Ottawa, Canada. ${ }^{8}$ Department of Epidemiology and Community Medicine, University of Ottawa, Ottawa, Canada. 
Received: 20 December 2018 Revised: 30 January 2019 Accepted: 11 February 2019 Published online: 06 March 2019

\section{References}

1. Simonneau G, Gatzoulis MA, Adatia I, Celermajer D, Denton C, Ghofrani A, et al. Updated clinical classification of pulmonary hypertension. J Am Coll Cardiol. 2013:62(25 Suppl):D34-41.

2. McLaughlin W, Archer SL, Badesch DB, Barst RJ, Farber HW, Lindner JR, et al. ACCF/AHA 2009 expert consensus document on pulmonary hypertension: a report of the American College of Cardiology Foundation Task Force on Expert Consensus Documents and the American Heart Association: developed in collaboration with the American College of Chest Physicians, American Thoracic Society, Inc., and the Pulmonary Hypertension Association. Circulation. 2009;119(16):2250-94.

3. Jurasz $P$, Courtman D, Babaie $S$, Stewart DJ. Role of apoptosis in pulmonary hypertension: from experimental models to clinical trials. Pharmacol Ther. 2010;126(1):1-8

4. Humbert M, Morrell NW, Archer SL, Stenmark KR, MacLean MR, Lang IM, et al. Cellular and molecular pathobiology of pulmonary arterial hypertension. J Am Coll Cardiol. 2004:43(12 Suppl S):13S-24S.

5. Schermuly RT, Ghofrani HA, Wilkins MR, Grimminger F. Mechanisms of disease: pulmonary arterial hypertension. Nat Rev Cardiol. 2011;8(8):443-55

6. Suen CM, Mei SH, Kugathasan L, Stewart DJ. Targeted delivery of genes to endothelial cells and cell- and gene-based therapy in pulmonary vascular diseases. Comprehensive Physiology. 2013;3(4):1749-79.

7. Granton J, Langleben D, Kutryk MB, Camack N, Galipeau J, Courtman DW, et al. Endothelial NO-synthase gene-enhanced progenitor cell therapy for pulmonary arterial hypertension: the PHACeT trial. Circ Res. 2015;117(7):645-54.

8. Foster WS, Suen CM, Cell SDJ. Tissue-based regenerative therapies for pulmonary arterial hypertension. Can J Cardiol. 2014

9. Takahashi T, Kalka C, Masuda H, Chen D, Silver M, Kearney M, et al. Ischemiaand cytokine-induced mobilization of bone marrow-derived endothelial progenitor cells for neovascularization. Nat Med. 1999:5(4):434-8.

10. Wang X-X, Zhang F-R, Shang Y-P, Zhu J-H, Xie X-D, Tao Q-M, et al. Transplantation of autologous endothelial progenitor cells may be beneficial in patients with idiopathic pulmonary arterial hypertension: a pilot randomized controlled trial. J Am Coll Cardiol. 2007:49(14):1566-71.

11. Zhu JH, Wang XX, Zhang FR, Shang YP, Tao QM, Zhu JH, et al. Safety and efficacy of autologous endothelial progenitor cells transplantation in children with idiopathic pulmonary arterial hypertension: open-label pilot study. Pediatr Transplant. 2008;12(6):650-5.

12. Suen CM, Zhai A, Lalu MM, Welsh C, Levac BM, Fergusson D, et al. Efficacy and safety of regenerative cell therapy for pulmonary arterial hypertension in animal models: a preclinical systematic review protocol. Syst Rev. 2016;5:89.

13. Moher D, Liberati A, Tetzlaff J, Altman DG. Preferred reporting items for systematic reviews and meta-analyses: the PRISMA statement. BMJ. 2009; 339:b2535.

14. Ryan JJ, Marsboom G, Archer SL. Rodent models of group 1 pulmonary hypertension. Handb Exp Pharmacol. 2013:218:105-49.

15. McGowan J, Sampson M, Lefebvre C. An evidence based checklist for the peer review of electronic search strategies (PRESS EBC). Evid Based Libr Inf Pract. 2010;5(1):149-54

16. Hooijmans CR, Rovers MM, de Vries RB, Leenaars M, Ritskes-Hoitinga M, Langendam MW. SYRCLE's risk of bias tool for animal studies. BMC Med Res Methodol. 2014;14(1):43

17. Higgins JP, Thompson SG. Quantifying heterogeneity in a meta-analysis Stat Med. 2002;21(11):1539-58.

18. Hayashino $Y$, Noguchi $Y$, Fukui T. Systematic evaluation and comparison of statistical tests for publication bias. J Epidemiol. 2005;15(6):235-43.

19. Takahashi M, Nakamura T, Toba T, Kajiwara N, Kato H, Shimizu Y. Transplantation of endothelial progenitor cells into the lung to alleviate pulmonary hypertension in dogs. Tissue Eng. 2004;10(5-6):771-9.

20. Luan Y, Zhang Z-H, Wei D-E, Lu Y, Wang Y-B. Effects of autologous bone marrow mononuclear cells implantation in canine model of pulmonary hypertension. Circ J. 2012;76(4):977-85.

21. Taraseviciene-Stewart L, Kasahara Y, Alger L, Hirth P, Mc Mahon G, Waltenberger J, et al. Inhibition of the VEGF receptor 2 combined with chronic hypoxia causes cell death-dependent pulmonary endothelial cell proliferation and severe pulmonary hypertension. FASEB J. 2001;15(2):427-38
22. Ormiston ML, Deng Y, Stewart DJ, Courtman DW. Innate immunity in the therapeutic actions of endothelial progenitor cells in pulmonary hypertension. Am J Respir Cell Mol Biol. 2010;43(5):546-54.

23. Thenappan T, Ormiston ML, Ryan JJ, Archer SL. Pulmonary arterial hypertension: pathogenesis and clinical management. BMJ. 2018;360:j5492

24. van de Veerdonk MC, Kind T, Marcus JT, Mauritz GJ, Heymans MW, Bogaard HJ, et al. Progressive right ventricular dysfunction in patients with pulmonary arterial hypertension responding to therapy. J Am Coll Cardiol. 2011;58(24):2511-9.

25. Ryan JJ, Archer SL. The right ventricle in pulmonary arterial hypertension: disorders of metabolism, angiogenesis and adrenergic signaling in right ventricular failure. Circ Res. 2014;115(1):176-88.

26. Hirst JA, Howick J, Aronson JK, Roberts N, Perera R, Koshiaris C, et al. The need for randomization in animal trials: an overview of systematic reviews. PLoS One. 2014:9(6):e98856.

27. Provencher S, Archer SL, Ramirez FD, Hibbert B, Paulin R, Boucherat O, et al. Standards and methodological rigor in pulmonary arterial hypertension preclinical and translational research. Circ Res. 2018;122(7):1021-32.

28. Henderson VC, Kimmelman J, Fergusson D, Grimshaw JM, Hackam DG. Threats to validity in the design and conduct of preclinical efficacy studies: a systematic review of guidelines for in vivo animal experiments. PLoS Med. 2013;10(7):e1001489.

29. Contopoulos-Ioannidis DG, Ntzani E, loannidis JP. Translation of highly promising basic science research into clinical applications. Am J Med. 2003;114(6):477-84

30. Luan Y, Zhang ZH, Wei DE, Zhao JJ, Kong F, Cheng GH, et al. Implantation of mesenchymal stem cells improves right ventricular impairments caused by experimental pulmonary hypertension. Am J Med Sci. 2012;343(5):402-6.

31. Granton J, Langleben D, Kutryk M, Camac N, Galipeau J, Courtman D, Stewart D. Endothelial NO-Synthase Gene-Enhanced Progenitor Cell Therapy for Pulmonary Arterial Hypertension. Circ Res. 2015;117:645-54.

32. Nagaya N, Kangawa K, Kanda M, Uematsu M, Horio T, Fukuyama N, et al. Hybrid cell-gene therapy for pulmonary hypertension based on phagocytosing action of endothelial progenitor cells. Circulation. 2003;108(7):889-95.

33. Zhao YD, Courtman DW, Deng Y, Kugathasan L, Zhang Q, Stewart DJ. Rescue of monocrotaline-induced pulmonary arterial hypertension using bone marrow-derived endothelial-like progenitor cells: efficacy of combined cell and eNOS gene therapy in established disease. Circ Res. 2005:96(4):442-50.

34. Kanki-Horimoto S, Horimoto H, Mieno S, Kishida K, Watanabe F, Furuya E, et al. Implantation of mesenchymal stem cells overexpressing endothelial nitric oxide synthase improves right ventricular impairments caused by pulmonary hypertension. Circulation. 2006;114(1 Suppl):1181-5.

35. Baber SR, Deng W, Master RG, Bunnell BA, Taylor BK, Murthy SN, et al. Intratracheal mesenchymal stem cell administration attenuates monocrotaline-induced pulmonary hypertension and endothelial dysfunction. Am J Physiol Heart Circ Physiol. 2007;292(2):H1120-8.

36. Yip HK, Chang LT, Sun CK, Sheu JJ, Chiang CH, Youssef AA, et al. Autologous transplantation of bone marrow-derived endothelial progenitor cells attenuates monocrotaline-induced pulmonary arterial hypertension in rats. Crit Care Med. 2008;36(3):873-80

37. Sun CK, Lee FY, Sheu JJ, Yuen CM, Chua S, Chung SY, et al. Early combined treatment with cilostazol and bone marrow-derived endothelial progenitor cells markedly attenuates pulmonary arterial hypertension in rats. J Pharmacol Exp Ther. 2009;330(3):718-26.

38. Umar S, de Visser YP, Steendijk P, Schutte Cl, el Laghmani H, Wagenaar GT, et al. Allogenic stem cell therapy improves right ventricular function by improving lung pathology in rats with pulmonary hypertension. Am J Physiol Heart Circ Physiol. 2009;297(5):H1606-16.

39. Takemiya K, Kai H, Yasukawa H, Tahara N, Kato S, Imaizumi T. Mesenchymal stem cell-based prostacyclin synthase gene therapy for pulmonary hypertension rats. Basic Res Cardiol. 2010;105(3):409-17.

40. Angelini A, Castellani C, Ravara B, Franzin C, Pozzobon M, Tavano R, et al. Stem-cell therapy in an experimental model of pulmonary hypertension and right heart failure: role of paracrine and neurohormonal milieu in the remodeling process. J Heart Lung Transplant. 2011;30(11):1281-93.

41. Mirsky R, Jahn S, Koskenvuo JW, Sievers RE, Yim SM, Ritner C, et al. Treatment of pulmonary arterial hypertension with circulating angiogenic cells. Am J Physiol Lung Cell Mol Physiol. 2011;301(1):L12-9.

42. Jiang $L$, Song $X H$, Liu $P$, Zeng $C L$, Huang $Z S$, Zhu $L$, et al. Platelet-mediated mesenchymal stem cells homing to the lung reduces monocrotalineinduced rat pulmonary hypertension. Cell Transplant. 2012;21(7):1463-75. 
43. Kim KC, Lee HR, Kim SJ, Cho MS, Hong YM. Changes of gene expression after bone marrow cell transfusion in rats with monocrotaline-induced pulmonary hypertension. J Korean Med Sci. 2012;27(6):605-13.

44. Sun CK, Lin YC, Yuen CM, Chua S, Chang LT, Sheu JJ, et al. Enhanced protection against pulmonary hypertension with sildenafil and endothelial progenitor cell in rats. Int J Cardiol. 2012;162(1):45-58.

45. Xie J, Hu D, Niu L, Qu S, Wang S, Liu S. Mesenchymal stem cells attenuate vascular remodeling in monocrotaline-induced pulmonary hypertension rats. J Huazhong Univ Sci Technolog Med Sci. 2012;32(6):810-7.

46. Yen CH, Tsai TH, Leu S, Chen YL, Chang LT, Chai HT, et al. Sildenafil improves long-term effect of endothelial progenitor cell-based treatment for monocrotaline-induced rat pulmonary arterial hypertension. Cytotherapy. 2013;15(2):209-23.

47. Zhou L, Chen Z, Vanderslice P, So SP, Ruan KH, Willerson JT, et al. Endothelial-like progenitor cells engineered to produce prostacyclin rescue monocrotaline-induced pulmonary arterial hypertension and provide right ventricle benefits. Circulation. 2013;128(9):982-94.

48. Chen JY, An R, Liu ZJ, Wang JJ, Chen SZ, Hong MM, et al. Therapeutic effects of mesenchymal stem cell-derived microvesicles on pulmonary arterial hypertension in rats. Acta Pharmacol Sin. 2014;35(9):1121-8.

49. Eguchi M, Ikeda S, Kusumoto S, Sato D, Koide Y, Kawano H, et al. Adiposederived regenerative cell therapy inhibits the progression of monocrotalineinduced pulmonary hypertension in rats. Life Sci. 2014;118(2):306-12.

50. Guo Y, Su L, Li Y, Guo N, Xie L, Zhang D, et al. The synergistic therapeutic effect of hepatocyte growth factor and granulocyte colony-stimulating factor on pulmonary hypertension in rats. Heart Vessel. 2014;29(4):520-31.

51. Luan Y, Zhang X, Qi TG, Cheng GH, Sun C, Kong F. Long-term research of stem cells in monocrotaline-induced pulmonary arterial hypertension. Clin Exp Med. 2014;14(4):439-46.

52. Somanna NK, Worner PM, Murthy SN, Pankey EA, Schachtele DJ, St Hilaire RC, et al. Intratracheal administration of cyclooxygenase-1-transduced adipose tissue-derived stem cells ameliorates monocrotaline-induced pulmonary hypertension in rats. Am J Physiol Heart Circ Physiol. 2014;307(8):H1 187-95.

53. Ikutomi M, Sahara M, Nakajima T, Minami Y, Morita T, Hirata Y, et al. Diverse contribution of bone marrow-derived late-outgrowth endothelial progenitor cells to vascular repair under pulmonary arterial hypertension and arterial neointimal formation. J Mol Cell Cardiol. 2015;86:121-35.

54. Kang H, Kim KH, Lim J, Kim YS, Heo J, Choi J, et al. The therapeutic effects of human mesenchymal stem cells primed with sphingosine-1 phosphate on pulmonary artery hypertension. Stem Cells Dev. 2015;24(14):1658-71.

55. Lee H, Lee JC, Kwon JH, Kim KC, Cho MS, Yang YS, et al. The effect of umbilical cord blood derived mesenchymal stem cells in monocrotalineinduced pulmonary artery hypertension rats. J Korean Med Sci. 2015;30(5):576-85.

56. Liang M, Li H, Zheng S, Ning J, Xu C, Wang H, et al. Comparison of early and delayed transplantation of adipose tissue-derived mesenchymal stem cells on pulmonary arterial function in monocrotaline-induced pulmonary arterial hypertensive rats. Eur Heart J Suppl. 2015;17(suppl_F):F4-F12.

57. Liu J, Han Z, Han Z, He Z. Mesenchymal stem cells suppress CaN/NFAT expression in the pulmonary arteries of rats with pulmonary hypertension. Exp Ther Med. 2015;10(5):1657-64.

58. Luo L, Lin T, Zheng S, Xie Z, Chen M, Lian G, et al. Adipose-derived stem cells attenuate pulmonary arterial hypertension and ameliorate pulmonary arterial remodeling in monocrotaline-induced pulmonary hypertensive rats. Clin Exp Hypertens. 2015;37(3):241-8.

59. YanYun P, Wang S, Yang J, Chen B, Sun Z, Ye L, et al. Interruption of CD40 pathway improves efficacy of transplanted endothelial progenitor cells in monocrotaline induced pulmonary arterial hypertension. Cell Physiol Biochem. 2015;36(2):683-96.

60. Chen $H$, Yang $H$, Yue H, Strappe PM, Xia P, Pan L, et al. Mesenchymal stem cells expressing eNOS and a Cav1 mutant inhibit vascular smooth muscle cell proliferation in a rat model of pulmonary hypertension. Heart Lung Circ. 2017;26(5):509-18.

61. Huang WC, Ke MW, Cheng CC, Chiou SH, Wann SR, Shu CW, et al. Therapeutic benefits of induced pluripotent stem cells in monocrotalineinduced pulmonary arterial hypertension. PLoS One. 2016;11(2):e0142476.

62. Kim KC, Lee JC, Lee H, Cho MS, Choi SJ, Hong YM. Changes in caspase-3, B cell leukemia/lymphoma-2, interleukin-6, tumor necrosis factor-alpha and vascular endothelial growth factor gene expression after human umbilical cord blood derived mesenchymal stem cells transfusion in pulmonary hypertension rat models. Korean Circ J. 2016;46(1):79-92.
63. Lim J, Kim Y, Heo J, Kim KH, Lee S, Lee SW, et al. Priming with ceramide-1 phosphate promotes the therapeutic effect of mesenchymal stem/stromal cells on pulmonary artery hypertension. Biochem Biophys Res Commun. 2016:473(1):35-41.

64. Rathinasabapathy A, Bruce E, Espejo A, Horowitz A, Sudhan DR, Nair A, et al. Therapeutic potential of adipose stem cell-derived conditioned medium against pulmonary hypertension and lung fibrosis. Br J Pharmacol. 2016;173(19):2859-79.

65. Varshney R, Ali Q, Wu C, Sun Z. Monocrotaline-induced pulmonary hypertension involves downregulation of antiaging protein klotho and eNOS activity. Hypertension. 2016;68(5):1255-63.

66. Ahmed LA, Rizk SM, El-Maraghy SA. Pinocembrin ex vivo preconditioning improves the therapeutic efficacy of endothelial progenitor cells in monocrotaline-induced pulmonary hypertension in rats. Biochem Pharmacol. 2017;138:193-204.

67. Cheng G, Wang X, Li Y, He L. Let-7a-transfected mesenchymal stem cells ameliorate monocrotaline-induced pulmonary hypertension by suppressing pulmonary artery smooth muscle cell growth through STAT3-BMPR2 signaling. Stem Cell Res Ther. 2017;8(1):34.

68. de Mendonca L, Felix NS, Blanco NG, Da Silva JS, Ferreira TP, Abreu SC, et al. Mesenchymal stromal cell therapy reduces lung inflammation and vascular remodeling and improves hemodynamics in experimental pulmonary arterial hypertension. Stem Cell Res Ther. 2017;8(1):220.

69. Lee H, Kim KC, Choi SJ, Hong YM. Optimal dose and timing of umbilical stem cells treatment in pulmonary arterial hypertensive rats. Yonsei Med J. 2017:58(3):570-80

70. Middleton RC, Fournier M, Xu X, Marban E, Lewis MI. Therapeutic benefits of intravenous cardiosphere-derived cell therapy in rats with pulmonary hypertension. PLoS One. 2017;12(8):e0183557.

71. Luo L, Zheng W, Lian G, Chen H, Li L, Xu C, et al. Combination treatment of adipose-derived stem cells and adiponectin attenuates pulmonary arterial hypertension in rats by inhibiting pulmonary arterial smooth muscle cell proliferation and regulating the AMPK/BMP/Smad pathway. Int J Mol Med. 2018;41(1):51-60.

\section{Ready to submit your research? Choose BMC and benefit from:}

- fast, convenient online submission

- thorough peer review by experienced researchers in your field

- rapid publication on acceptance

- support for research data, including large and complex data types

- gold Open Access which fosters wider collaboration and increased citations

- maximum visibility for your research: over 100M website views per year

At BMC, research is always in progress.

Learn more biomedcentral.com/submissions 